\title{
Open-access row leads paper to shed authors
}

\section{Declan Butler}

A spat between the New England Journal of Medicine (NEJM) and one of the leaders of a movement for open access to the scientific literature has resulted in the journal rejecting a paper on kidney transplants at the last minute - and immediately reaccepting it without the names of four of the original authors.

Caught up in the disagreement is Minnie Sarwal, a young researcher at Stanford University School of Medicine in California, the lead author of the paper, "Molecular heterogeneity in acute renal allograft rejection identified by DNA microarray profiling" (M. Sarwal, et al. N. Engl. J. Med. 349, 125-138; 2003), which was finally published on 10 July.

One of her Stanford co-authors, Patrick Brown, says he wanted the paper to be sent to an open-access journal, but reluctantly agreed to the NEJM as this was important for Sarwal's career. Brown is a co-founder of the Public Library of Science (PLoS), which launches its first open-access journal next month. Papers published in PLoS journals are freely available from the time at which they are published, whereas most journals make papers available only to subscribers, for a period of time at least — six months in the case of the NEJM.

Brown says that he insisted that the NEJM publish the paper under the terms of the PLoS open-access licence, which stipulates that the authors retain copyright but agree to allow the unrestricted use, distribution and reproduction of the article in any form, provided that the original work is properly cited.

The terms on which the paper was originally accepted are now hotly disputed, however. When Brown received the galley proofs in June, a sentence — "This article is published under the terms of the PLOS open access license" - had been deleted from a previously agreed edit of the paper. Jeffrey Drazen, editor-in-chief of the NEJM, says that the sentence was only spotted at the last minute, and was unacceptable.

Drazen says that the offending sentence was not present in the original submitted paper, and was added later. Brown admits this, but maintains that the journal understood his terms from the outset. He had annotated the copyright form, for example, to read that submission was "entirely subject to the condition that the work in question will be made freely available for distribution and use by anyone within six months of publication".

But Drazen is equally adamant that he would never have agreed to the PLoS licence terms, and that the NEJM's editors had thought that the authors' demands were covered by the journal's standard policy.

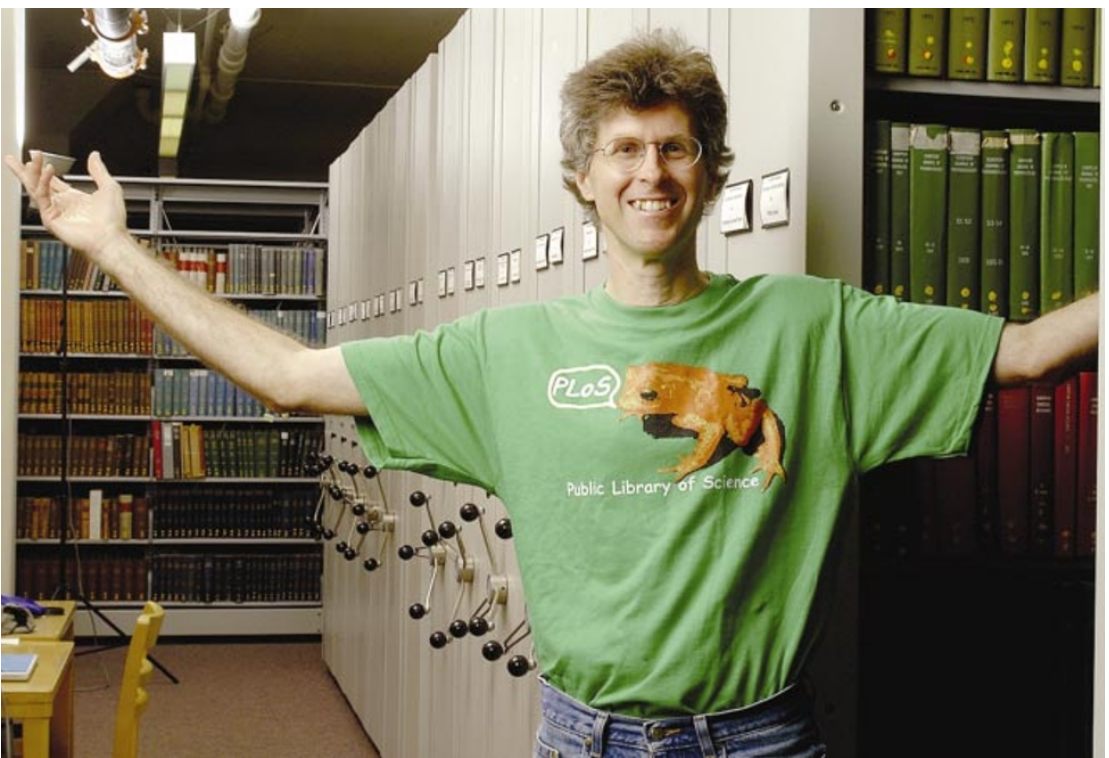

Free for all: Pat Brown wants all published scientific research to be freely available.

Sarwal, who carried out the initial communications with NEJM, admits this possibility. "This misunderstanding may have occurred. Brown kind of let me know what sentences to write in the [covering] letter and the paper and I did so. I am sad it turned out the way it did."

Drazen's decision to delete the PLoS rider presented Brown with a dilemma. He says that he wanted to withdraw the paper in protest, but felt that the results were important, and should be published without further delay. Sarwal also did not want to retract the paper, as she had distributed the galleys in confidence in support of a grant proposal.

Instead, Brown called Drazen and demanded that his name and that of three other authors be withdrawn from the paper, and that this be explained in the published manuscript. Drazen refused. In a 5 June e-mail to Brown, he wrote: "We are withdrawing acceptance because all eleven original authors signed a letter, dated October

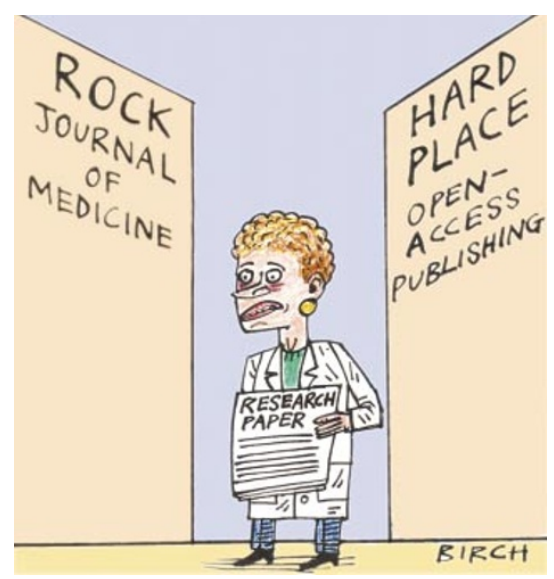

22, 2002, certifying that they were the sole authors of the work. Thus, we cannot subsequently represent to our readers that the remaining seven authors are the only authors of the entire paper."

The paper was rejected, and a new one accepted, after Brown asked Drazen to reconsider, suggesting that the deleted authors be acknowledged as having contributed to the experiments, and sharing responsibility for the results.

Drazen says that he agreed to reaccept the paper only after Sarwal confirmed that the new authorship represented the sole authors of the work, with Brown's team being important contributors. The paper was immediately published. Brown subsequently contacted Nature to persuade this journal to cover the story.

The spat has resulted in name-calling on both sides. Brown alleges that the events constitute a "clear and documented case of editorial misconduct in the handling of an article", and that the change in authorship is "manuscript laundering".

In a statement, the NEJM asserts: "It is unfortunate that Dr Brown chose to use important medical research affecting renal transplant patients to generate publicity for his planned publishing ventures. A researcher of his experience knows well that the Journal cannot selectively ignore copyright laws so that individual authors can draw attention to a personal cause. He placed his desire to promote his personal interest above his responsibility to his research colleagues."

For her part, Sarwal says: "I am just a young scientist trying to do good science and feel terrible that any of this occurred." 